\title{
A hepatocellularis carcinoma elófordulása és kezelésének tanulságai az északkelet-magyarországi régióban
}

\author{
Papp Renáta dr. ${ }^{1}$ - Papp Mária dr. ${ }^{2}$ \\ Tornai István dr. $^{2}$. Vitális Zsuzsanna dr. ${ }^{2}$ \\ ${ }^{1}$ Koch Róbert Kórház és Rendelőintézet, Edelény \\ ${ }^{2}$ Debreceni Egyetem, Általános Orvostudományi Kar, Belgyógyászati Intézet, \\ Gasztroenterológia Nem Önálló Tanszék, Debrecen
}

\begin{abstract}
Bevezetés: A hepatocellularis carcinoma gyakori, nehezen kezelhető daganat. Célkitüzés: A szerzók áttekintették a májsejtrákkal kapcsolatos ismereteket és értékelték a kezelési eredményeket az északkelet-magyarországi régióban. Módszer: A szerzők intézményében 5 év alatt májsejtrák diagnózissal kezelt betegek adatait retrospektív módon elemezték. Eredmények: Ismert májcirrhosisa 187 beteg közül 71-nek (38\%) volt, 52 betegnél (28\%) a májcirrhosisra a daganat felismerésekor derült fény. Nem volt májzsugora 15 betegnek (8\%), míg erre vonatkozóan 49 betegnél (26\%) nem találtak adatot. Etiológiai faktorok az alkoholfogyasztás (52\%), a vírushepatitis (41\%) és a metabolikus szindróma (valószínúleg nem alkoholos zsírmáj) (44\%) voltak. Cirrhosis nélkül kialakult májsejtrák hátterében leggyakrabban nem alkoholos zsírmáj állt. A daganat felismerése 83\%-ban előrehaladott stádiumban történt. A túlélést a Barcelona stádium (A vs. B/C vs. D stádium: 829 vs. 387 vs. 137 nap, p<0,001) jelentősen befolyásolta, az etiológia nem (vírus 282, metabolikus szindróma 335 és alkohol 423 nap, $\mathrm{p}=0,65$ ). Következtetések: A hepatocellularis carcinoma rossz kimenetelének oka a késői felismerés. A májzsugoros betegek szűrése mellett a májcirrhosis korábbi felismerése szükséges. A metabolikus szindrómások ultrahangos szûrése megfontolandó. A krónikus májbetegség terápiája a túlélést lényegesen befolyásolja. Orv. Hetil., 2016, 157(45), 1793-1801.
\end{abstract}

Kulcsszavak: hepatocellularis carcinoma, krónikus májbetegség, cirrhosis, szűrés, Barcelona stádium

\section{Incidence of hepatocellular carcinoma and consequent lessons for its management in Northeastern Hungary}

Introduction: The increasing incidence and poor prognosis of hepatocellular carcinoma places huge burden on healthcare. Aim: After reviewing literature on epidemiological trends, risk factors, diagnosis and management options for hepatocellular carcinoma, the authors investigated results of treatment and survival data of patients in Northeastern Hungary. Method: In a retrospective study, the authors analyzed medical records of 187 patients with hepatocellular carcinoma (etiology, presence of cirrhosis, stage of the tumor, treatment and disease outcome). Results: Seventy-one patients $(38 \%)$ had known cirrhosis at the diagnosis of hepatocellular carcinoma, while in 52 patients $(28 \%)$ the presence of cirrhosis was established at the time of the diagnosis of hepatocellular carcinoma. Fifteen patients $(8 \%)$ had no cirrhosis and in 49 patients $(26 \%)$ no data were available regarding cirrhosis. Etiological factors were alcohol consumption $(52 \%)$, viral hepatitis (41\%) and metabolic syndrome (44\%). In cases of metabolic syndrome, hepatocellular carcinoma frequently occurred without cirrhosis. In $83 \%$ of the cases, the tumor was discovered in an advanced stage. Median survival time was significantly associated with tumor stage (Barcelona A stage vs. B/C vs. D: 829 vs. 387 vs. 137 days, respectively $\mathrm{p}<0.001$ ) but not with disease etiology (virus 282 days, metabolic syndrome 335 days and alcohol 423 days, $\mathrm{p}=0.65$ ). Conclusions: High mortality of hepatocellular carcinoma was mainly attributed to the delayed diagnosis of the disease. Screening of patients with cirrhosis could only result in a partial improvement since in a great proportion cirrhosis was diagnosed simultaneously with the tumor. Screening of diabetic and obese patients by ultrasonography should be considered. Management of baseline liver disease is of importance in the care of hepatocellular carcinoma.

Keywords: hepatocellular carcinoma, chronic liver disease, cirrhosis, screening, Barcelona stage

Papp, R., Papp, M., Tornai, I., Vitális, Zs. [Incidence of hepatocellular carcinoma and consequent lessons for its management in Northeastern Hungary]. Orv. Hetil., 2016, 157(45), 1793-1801.

(Beérkezett: 2016. július 14.; elfogadva: 2016. augusztus 22.) 


\section{Rövidítések}

AFP = alfa-foetoprotein; BCLC = Barcelona Clinic Liver Cancer (a májsejtrák barcelonai stádiumbeosztása); CT = komputertomográf; DNS = dezoxiribonukleinsav; $\mathrm{HBV}=$ hepatitis $\mathrm{B}$-vírus; $\mathrm{HCC}=$ hepatocellularis carcinoma; $\mathrm{HCV}=$ hepatitis $\mathrm{C}$-vírus; $\mathrm{MRI}=$ (magnetic resonance imaging $)$ mágneses rezonanciavizsgálat; $\mathrm{MS}=$ metabolikus szindróma; $\mathrm{NASH}=$ nem alkoholos steatohepatitis; PDGFR $=$ (platelet-derived growth factor receptor) thrombocytaeredetú növekedési faktor receptor; PEI = percutan etanolinjekció; PST $=$ Performance Status Test (globális funkcionális állapotfelmérési teszt); RFA = rádiófrekvenciás ablatio; RNS $=$ ribonukleinsav; TACE $=$ transarterialis chemoembolisatio; TP53 = tumorprotein 53; $\mathrm{UH}=$ ultrahang; VEGF = (vascular endothelial growth factor $)$ vascularis endothelialis növekedési faktor

A hepatocellularis carcinoma (HCC) a férfiaknál az ötödik, a nóknél a hetedik leggyakoribb malignus betegség, míg a daganat okozta halálozásban a 3 . helyen áll, ami azt jelzi, hogy a kurabilitása nagyon rossz [1]. Szinte kizárólag krónikus májbetegség talaján alakul ki, általában annak cirrhoticus fázisában (70-90\%). Ritkán előfordul, hogy korábban, a krónikus regeneráció időszakában jelenik meg [2]. A májzsugor annak bármely stádiumában és bármely etiológia esetén a HCC kialakulásának fokozott kockázatával jár. A májzsugorban szenvedők 30-35\%ában várható a tumor megjelenése [3]. A világstatisztikai adatok szerint leggyakrabban vírushepatitis (körülbelül $50 \%$ ), alkoholos májkárosodás (mintegy $25 \%$ ) vagy nem alkoholos steatohepatitis áll a háttérben (megközelítőleg 10\%), de ezek mellett minden olyan betegség, amely májzsugor kialakulásához vezethet, szerepelhet oki tényezőként a tumor patogenezisében. A májcirrhosis felismerése nem mindig egyszerü. A máj krónikus károsodása ellenére még sokáig képes ellátni feladatát, ezért alattomos, tünetei viszonylag későn jelentkeznek.

A hepatitis B-vírus, a gazdaszervezet genomjába integrálódó DNS-e révén, pontmutációt hoz létre a TP53 tumorszuppresszor génben, ilyen módon direkt carcinogen. A hepatitis $C$-vírus esetén az évtizedekig tartó krónikus gyulladás által okozott sejtproliferációt tartják felelősnek. Az alkoholfogyasztás [4], az aflatoxin, a dohányzás, az orális fogamzásgátlók, az elhízás és a metabolikus szindróma biztosan növeli, a szerves oldószerek közül a tetraklór-etilén, szén-tetraklorid és a kloroform nagy valószínűséggel növeli a daganat kialakulásának esélyét [4].

Specifikusan HCC-re jellemző panasz nincs, az esetek döntő többségében a májzsugor vagy krónikus májbetegség által okozott klinikai tünetek és elváltozások állnak előtérben. Cirrhoticus betegekben a betegség dekompenzálódása, az ascites véressé válása, a láz és a májtáji fájdalom megjelenése hívhatja fel rá a figyelmet. Előfordulhat, hogy a kompenzált májzsugor megelőzően tünetmentes és csak a daganat diagnózisa során kerül felismerésre.
A HCC jellegzetessége a multifokális megjelenés. Korán ad áttétet, leggyakrabban a tüdőbe, csontokba.

A diagnózis sarokkövei a képalkotó vizsgálatok, az ultrahang (UH), a komputertomográf (CT) és a mágneses rezonanciavizsgálat (MRI). Egyes tanulmányok szerint a HCC diagnózisában az UH érzékenysége 30-100\% [2], ami alig különbözik a CT szenzitivitásától (68-91\%). Az MRI szenzitivitása 77-100\%. Nagyobb elváltozás esetén (>2 cm) mindhárom vizsgálóeljárás közel 100\%-os biztonsággal igazolja a daganatot, de $1-2 \mathrm{~cm}$-es vagy ennél kisebb méretû daganat esetén az érzékenység csak 40$80 \%$ [5].

Az esetek csaknem felében megemelkedik az alfa-foetoprotein ( $A F P$ ) szintje. Sajnos nem specifikus, szérumszintjének emelkedését számos egyéb állapot előidézheti (cirrhosis, krónikus hepatitis, terhesség, csírasejtes daganatok). Nagyon magas szint (>1000 ng/ml) azonban szinte kizárólag HCC következtében alakul ki, de általában nagy tumorméret esetén [6].

A diagnózis alátámasztásához hazánkban $\mathrm{UH}$ - vagy CT-vezérelt biopszia, illetve a minta szövettani vizsgálata szükséges. A mintavétel megerősíti a diagnózist, ha a képalkotók alapján bizonytalanság merülne fel, viszont nem mindig kivitelezhető, és az esetek egyharmadában fals negatív eredményt ad. Lehetséges szövődménye a vérzés és a tumor szóródása [7]. Jelenlegi nemzetközi álláspont szerint 2 független dinamikus képalkotó vagy 1 dinamikus képalkotó AFP-emelkedés mellett elegendő a HCC diagnózisának a kimondásához.

A Barcelona stádiumbeosztás (BCLC) [8] figyelembe veszi a tumor kiterjedtségén kívül a májzsugor stádiumát és a beteg általános állapotát (1. ábra). A BCLC-beosztás óriási előnye az, hogy az öt stádiumba (0-A-B-C-D) való besorolás terápiás algoritmust is jelent, így megszabja a beteg onkológiai kezelését. Az általános állapotot a PST-teszt (Performance Status Test) segítségével mérik fel, a májzsugor súlyosságát pedig a Child-Pughstádiumbeosztással.

Korán felismert betegség esetén, tehát Barcelona 0-A stádiumban van lehetőség csupán kuratív terápiára, amely kis szoliter gócok és kompenzált májmúködés esetén májreszekciót, esetleg májtranszplantációt vagy percutan ablatiót jelent. A reszekció csak a sebészi reszekciós vonalak mentén történhet (fontos a megmaradt máj vérrel és epecsatornával történő ellátottsága), amely mindenképpen a tumor méretéhez képest jelentősebb parenchymavesztéssel jár. A legtöbbször jelen lévő májzsugor miatt a mútét előtt mérlegelni kell a maradék máj rezerv kapacitását [3]. A BCLC szerinti korai (A), illetve igen korai (0) stádiumban a mútétet követően az 5 éves túlélés 70 és 90\% [9]. A javuló mútéti technikák és perioperatív ellátás hatására a reszekció rövid távú eredményei folyamatosan javulnak.

A májtranszplantáció nemcsak a daganat összes gócának eltávolítását jelenti - függetlenül annak lokalizációjától -, hanem a legfontosabb rizikófaktornak, a májcirrhosisnak az eliminálását is. A transzplantációt követően 


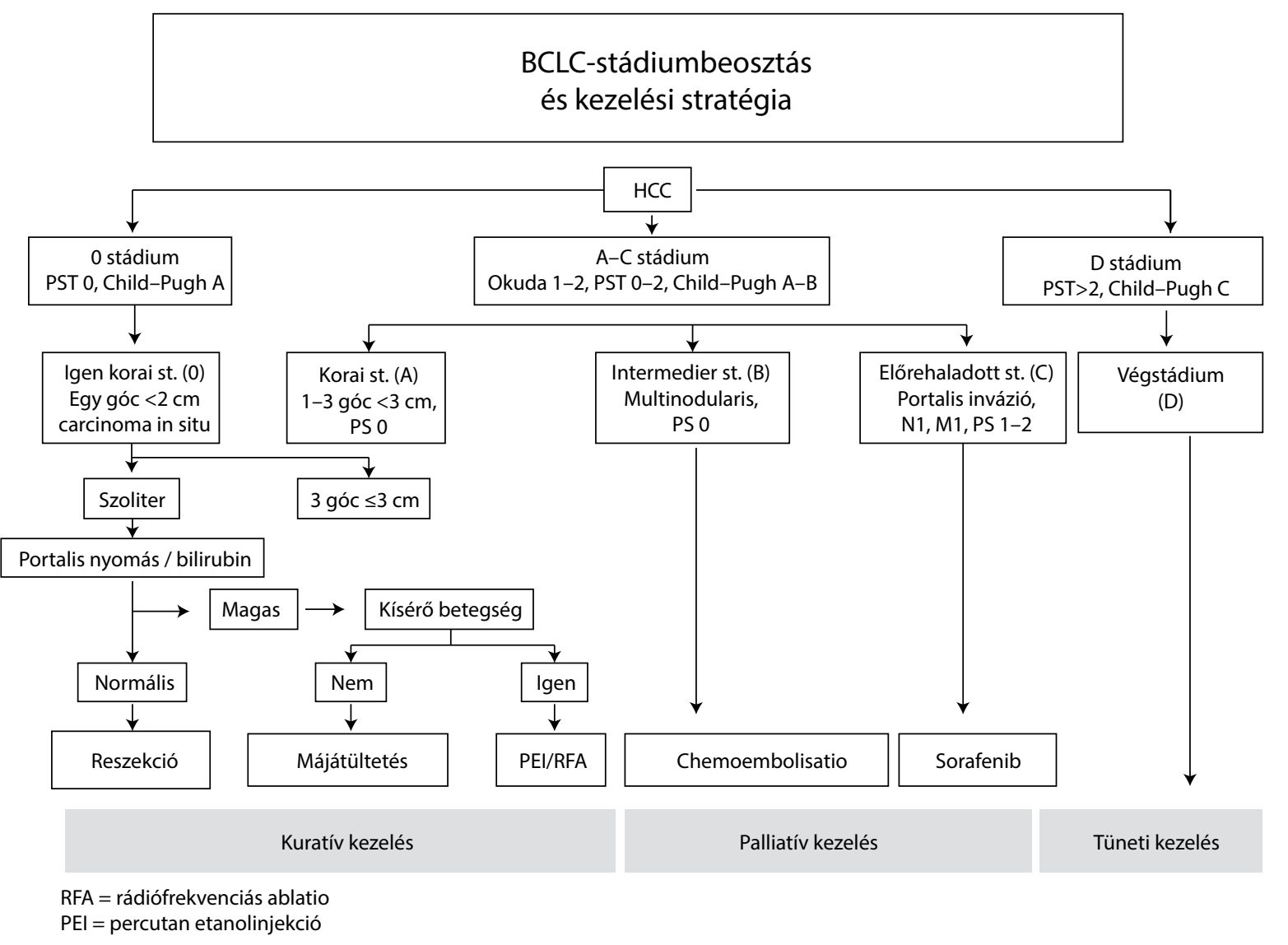

1. ábra

| A hepatocellularis carcinoma stádiumbeosztása [8]

szükséges immunszuppresszió daganatszóródást provokál, emiatt szigorú kritériumokhoz kötik elvégezhetôségét. A beteg a milánói kritériumoknak meg kell, hogy feleljen (3-nál nem több gócú és $3 \mathrm{~cm}$-nél nem nagyobb, vagy szoliter eltérés esetén, $5 \mathrm{~cm}$-nél kisebb góc). Sajnos a várakozási idő alatt a betegség progrediálhat, emiatt kiegészítő kezelésre lehet szükség.

$\mathrm{Az}$ ablatiós technikák rádiófrekvenciás ablatiót (RFA) vagy percutan etanolinjekciót (PEI) jelentenek. Az előbbi hő, az utóbbi pedig kémiai úton idéz elő sejtnekrózist. Mivel az RFA hatékonyabb, a PEI alkalmazási területe csökkent. A legnagyobb méretü tumor, amelynek ablatiója még sikeres lehet, RFA esetén $5 \mathrm{~cm}$, ennél nagyobb átmérőjü HCC-ben önmagában kevésbé, chemoembolisatióval kombinálva jobb eredménnyel alkalmazható $[10,11]$. Az RFA jól tolerálható, hatékony. Általában 1-3 beavatkozás elegendő a tumor eliminációjához megfelelő indikáció esetén. Szövődményei ritkák: portathrombosis, vérzés, májtályog fordulhat elő [12].

A milánói kritériumok teljesülése esetén, ha a transzplantációra nincs lehetőség, sebészi reszekció vagy RFA között kell dönteni. Az RFA kisebb megterheléssel jár (halálozás $0,9 \%$ vs. reszekció során várható 3\%) [13]. A kezelés költsége alacsonyabb. A reszekciót kontraindikáló ok lehet a tumorgócok lokalizációja (centrális tumor, egymástól távol eső gócok, amelyek nagyarányú parenchymavesztéssel járnának). Az egyéves túlélési eredmények a reszekció és az RFA esetén hasonlóak voltak (90-95\%), azonban az 5 éves túlélés szignifikánsan jobb a sebészi megoldás esetén (60-70\% vs. 40-50\%). Mindkét esetben a fó problémát a recidíva jelenti. A reszekció 5 éves túlélési előnyét valószínúleg az magyarázza, hogy a kimetszett lebennyel a nem észlelt kisebb gócok is eltávolításra kerülnek, amelyeket az ablatiós kezelés nem érint [14].

Előrehaladottabb folyamat esetén tumorgyógyulás nem várható. Chemoembolisatio vagy szisztémásan alkalmazott sorafenib a túlélést javítja.

Transarterialis chemoembolisatio (TACE) során a tumoros szövet vérellátásában jelentősebb szereppel bíró arteria hepaticába, illetve annak ágába doxorubicint, cisplatint adva nagy koncentráció érhető el a daganatszövetben, amelynek kimosódása a tumort tápláló ér elzárásával késleltethető a hosszabb behatás biztosítása céljából. Így a kezelés ischaemiás effektusa egy erős citotoxikus hatással kombinálható [15].

Nagyobb tumortömeg, de kompenzált májmúködés esetén sorafenib adása jön szóba, amely az egyetlen hatékony szisztémásan adható kemoterápiás szer HCC-ben, egy multitirozinkináz-inhibitor, amely az angiogenetikus jelátvitel számos kulcsfontosságú modulátorát blokkolja (sejtfelszíni VEGF- és PDGFR-receptorok, intracelluláris szerin/treonin kinázok) [16]. Dekompenzált májcirrhosis esetén (Barcelona D stádium) csak tüneti terápiára 
van lehetőség a beteg életminőségének lehetőség szerinti javítása céljából (megfelelő táplálás, tünetek csökkentése, fájdalomcsillapítás, a májzsugor komplikációinak ellátása).

\section{Betegek és módszer}

A Debreceni Egyetem MedSolution adatbázisában a 2009. január 1. és 2014. február 15. közötti időszakban C2290 (májsejtrák) kóddal lezárt páciensek adatait tekintettük át, illetve kiválogattuk és Microsoft Excel táblázatban rögzítettük a HCC-s eseteket. Azon betegeket tekintettük bizonyítottan HCC-snek, akiknél a diagnózist szövettani vizsgálattal alátámasztották. Ezekben az esetekben megvizsgáltuk az etiológiai faktorokat, a májzsugor meglétét és stádiumát, a daganat kiterjedtségét, illetve előrehaladottságát. A cirrhosis meglétének alátámasztásához átnéztük a betegek rögzített fizikális eltéréseit, UH-leleteit, laboradatait, szövettani eredményeit, és kompenzált cirrhosis esetében klinikai jelek hiányában a szövettani eredményeket vettük figyelembe.

A májzsugor Child-Pugh-stádiumokba való besorolásakor a diagnózis időpontjában történt laborvizsgálat eredményét, illetve a statusban szereplő ascitest és encephalopathiát vettük alapul.

Kigyüjtöttük a daganat diagnosztizálásának, a cirrhosis felismerésének, a terápia megkezdésének, illetve a halál beálltának időpontjait, amelyekből medián túléléseket számítottunk. Külön vizsgáltuk a cirrhosis meglététől, az egyes etiológiáktól, a májzsugor előrehaladottságától, illetve a daganat stádiumától függő túléléseket. Az etiológia rögzítésekor azokat a betegeket, akik elhízottak voltak, diabetesük ismert volt, illetve a képalkotókkal zsírmáj került leírásra, a metabolikus szindrómások csoportjába soroltuk. Valójában ők azok, akiknek nagy valószínúséggel nem alkoholos zsírmájuk, steatohepatitisük lehetett, amely önmagában vagy egyéb etiológiai tényezőkkel együtt a HCC kialakulásában szerepet játszott. A NASH kimondásához korábbi szövettani vizsgálat nem állt rendelkezésre. A májzsugoros betegek esetén megnéztük, hogy a cirrhosis ismert volt-e a HCC diagnózisa elött vagy csak a tumor diagnózisának időpontjában került felismerésre.

Azoknál a betegeknél, akiknél a MedSolution rendszerből nem derült ki az elhalálozás időpontja, az erre vonatkozó adatokat a Hajdú-Bihar Megyei Kormányhivataltól kértük le. A tumor Barcelona stádiumának meghatározásához áttekintettük a rendelkezésre álló CT- és UH-leleteket, valamint az operáción átesett betegek esetén a mütéti leírást, amelyekből kigyújtöttük a tumor méretére vonatkozó adatokat. Általános állapottal kapcsolatos információk szinte egyáltalán nem kerültek rögzítésre a betegek dokumentációjában. A milánói kritériumon belüli csoportba soroltuk a tumort, ha 3-nál nem több gócú és $3 \mathrm{~cm}$-nél nem nagyobb, illetve szoliter eltérés esetén $5 \mathrm{~cm}$-nél kisebb volt az elváltozás. Kigyưjtöttük az elsőként alkalmazott kezeléseket és összehasonlítottuk a Barcelona stádiumbeosztás alapján ajánlottal, kiértékelve, hogy a kezelés megválasztása az ajánlásoknak megfelelően történt-e.

Megvizsgáltuk a választott kezelésektől függő túléléseket, amelyeket összehasonlítottunk a nemzetközi adatokkal. Vizsgáltuk az átlagéletkort, illetve a nemek arányát.

A munkánkat jelentősen megnehezítette, hogy az adatok hiányosak voltak. Mivel a betegek többségénél nem volt hozzáférhető az összes vizsgált paraméter, ezért, hogy reálisak maradjanak az arányok, minden esetben azt tekintettük 100\%-nak, ahány adat az adott jellemzővel kapcsolatban rendelkezésünkre állt. Emellett a betegpopuláció is kis összlétszámú volt, előfordult, hogy egyes vizsgált jellemzőnek mindössze néhány ember felelt meg, így ezen adataink statisztikai számítások elvégzésére nem alkalmasak, belőlük a következtetések csak fenntartásokkal vonhatók le.

\section{Eredmények}

A májsejtrákkal kódolt 401 betegből 187 volt bizonyítottan HCC-s. Egyéb daganata (döntő többségükben cholangiocellularis carcinoma, illetve adenocarcinomametastasis) 214 betegnek volt. Az átlagéletkor 64 év (SD

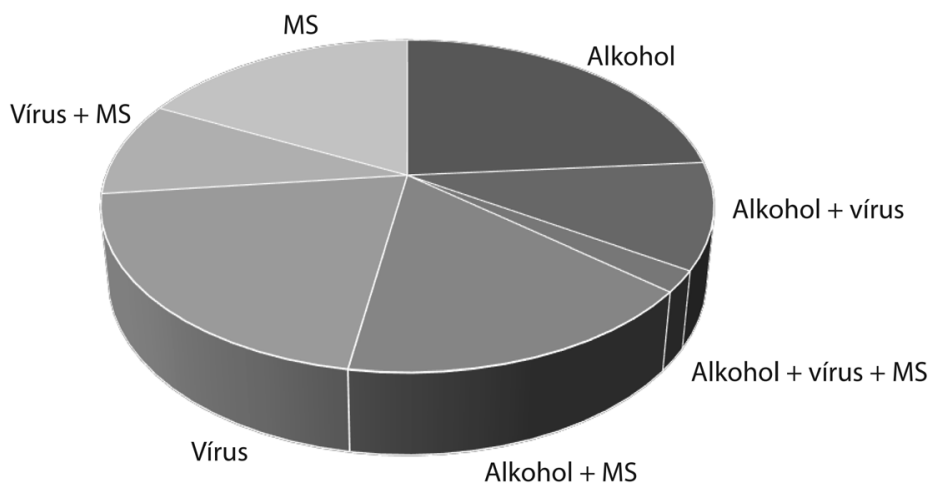

Betegszám: 149 (80\%)

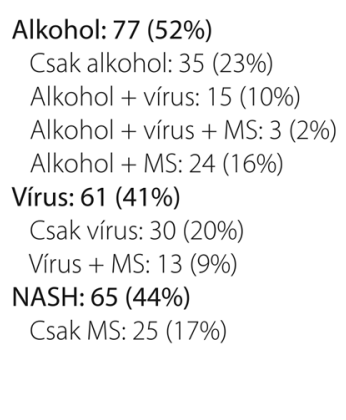

2. ábra

A hepatocellularis carcinoma etiológiai megoszlása betegeinkben

Etiológiai adat 149 beteg esetén állt rendelkezésre, ezt tekintettük 100\%-nak 
1. táblázat |A HCC etiológiája betegeinkben

\begin{tabular}{ll}
\hline $\begin{array}{l}\text { Összesen } \\
\mathrm{n}(\%)\end{array}$ & $187(100 \%)$ \\
\hline $\begin{array}{l}\text { Cirrhosis van, } \\
\mathrm{n}(\%)\end{array}$ & $123 / 187(66 \%)$ \\
\hline $\begin{array}{l}\text { Cirrhosis nincs, } \\
\mathrm{n}(\%)\end{array}$ & $15 / 187(8 \%)$ \\
\hline $\begin{array}{l}\text { Nem ismert, } \\
\mathrm{n}(\%)\end{array}$ & $49 / 187(26 \%)$ \\
\hline
\end{tabular}

n = betegszám

$12,43)$. 143 férfi $(76,5 \%)$ és 44 nő- $(23,5 \%)$ betegünk volt. A betegek 19\%-a élt a vizsgálat befejezésekor, 5\%uk volt tumormentes a követési idő alatt. Az 5 éves túlélés $7 \%$, de voltak betegek, akiknél a tanulmány lezárásakor a követési idő még nem érte el az 5 évet (31 beteg).

Etiológiával kapcsolatos adat betegeink 80\%-ában (149 eset) állt rendelkezésre (2. ábra). A HCC kialakulásában az alkohol 77 esetben (52\%), a vírus 61 esetben $(41 \%)$, a metabolikus szindróma 65 esetben (44\%) szerepelt önállóan vagy részben oki tényezőként. Csak alkohol 35 esetben $(23 \%)$, csak vírus 30 esetben $(20 \%)$, csak metabolikus szindróma 25 esetben (17\%) vezetett HCChez. A betegek többségét kevert etiológia jellemezte.

Alkohol és vírus együttesen 15 betegnél (10\%), az alkohol és metabolikus szindróma 24 betegnél (16\%), a ví- rus és metabolikus szindróma 13 betegnél (9\%) okozta az elváltozást. Alkoholos, vírusos és metabolikus szindrómás elózménye 3 betegnek (2\%) volt.

Bizonyítottan 123 betegnek (66\%) volt májzsugora, amit 71 esetben $(58 \%)$ már a HCC diagnózisa előtt felismertek, 52 alkalommal (42\%) azonban csak a tumor diagnózisakor derült rá fény (1. és 2. táblázat). Eredményeink alapján az ismert alkoholfogyasztóknak és vírusos betegeknek volt jobb esélye a májzsugor időben történő felismerésére, ugyanis az alkoholos eredet mellett 69\%ban, vírusos etiológia esetén $63 \%$-ban a tumor diagnózisa előtt felfedezésre került a májzsugor.

Daganatos elváltozása 15 betegnek (a 138 beteg 11\%ának) bizonyíthatóan nem cirrhosis talaján alakult ki. A nem cirrhoticus talajon megjelent HCC hátterében leggyakrabban metabolikus szindróma (feltételezhetóen $\mathrm{NASH}$ ) állt ( 15 beteg közül 6 esetben) (3. táblázat). Az etiológiáról 15 közül 5 esetben nincs információ, ami az arányokat jelentősen torzíthatja. Az esetleges májzsugor tisztázása érdekében sajnos a betegek 26\%-ánál semmilyen vizsgálat nem történt (1. táblázat), ami a gondozás szempontjából elengedhetetlenül fontos.

A felismeréskor detektált tumorstádium összefüggött azzal, hogy a betegnek ismert volt-e megelőzően a cirrhosisa. A nem cirrhosisos, illetve a fel nem ismert cirrhosisos csoportban alacsonyabb arányban (37, illetve $23 \%$ ban) diagnosztizálták a milánói kritériumon belül a

2. táblázat |A cirrhosis talaján kialakult HCC etiológiája betegeinkben

\begin{tabular}{|c|c|c|c|c|c|c|}
\hline & Cirrhosis felismerése & $\begin{array}{l}\text { Alkohol, } \\
\mathrm{n}(\%) \\
65\end{array}$ & $\begin{array}{l}\text { Vírus, } \\
\mathrm{n}(\%) \\
47\end{array}$ & $\begin{array}{l}\text { MS, } \\
\text { n }(\%) \\
48\end{array}$ & $\begin{array}{l}\text { Egyéb, } \\
\text { n (\%) } \\
3\end{array}$ & $\begin{array}{l}\text { Nem ismert, } \\
\mathrm{n}(\%) \\
10\end{array}$ \\
\hline \multirow{2}{*}{$\begin{array}{l}\text { Cirrhosisa van, } \\
\mathrm{n}=123\end{array}$} & $\begin{array}{l}\text { HCC diagnózisa előtt } \\
71 / 123 \\
(58 \%)\end{array}$ & $\begin{array}{l}45 / 65 \\
(69 \%)\end{array}$ & $\begin{array}{l}30 / 47 \\
(63 \%)\end{array}$ & $\begin{array}{l}28 / 48 \\
(58 \%)\end{array}$ & $\begin{array}{l}3 / 3 \\
(100 \%)\end{array}$ & $\begin{array}{l}2 / 10 \\
(20 \%)\end{array}$ \\
\hline & $\begin{array}{l}\text { HCC diagnózisakor } \\
52 / 123 \\
(42 \%)\end{array}$ & $\begin{array}{l}20 / 65 \\
(31 \%)\end{array}$ & $\begin{array}{l}17 / 47 \\
(37 \%)\end{array}$ & $\begin{array}{l}20 / 48 \\
(42 \%)\end{array}$ & 0 & $\begin{array}{l}8 / 10 \\
(80 \%)\end{array}$ \\
\hline
\end{tabular}

$\mathrm{n}$ = betegszám.

(Kevert etiológiák miatt 1-1 beteg több etiológia alatt is szerepel.)

3. táblázat | Cirrhosis talaján és cirrhosis nélkül kialakult HCC etiológiai megoszlása

\begin{tabular}{|c|c|c|c|c|c|c|}
\hline & $\begin{array}{l}\text { Összesen, } \\
\mathrm{n}(\%) \\
138\end{array}$ & $\begin{array}{l}\text { Alkohol, } \\
\text { n (\%) } \\
69\end{array}$ & $\begin{array}{l}\text { Vírus, } \\
\mathrm{n}(\%) \\
50\end{array}$ & $\begin{array}{l}\text { MS, } \\
\mathrm{n}(\%) \\
54\end{array}$ & $\begin{array}{l}\text { Egyéb, } \\
\text { n (\%) } \\
3\end{array}$ & $\begin{array}{l}\text { Nem ismert, } \\
\mathrm{n}(\%) \\
15\end{array}$ \\
\hline $\begin{array}{l}\text { Cirrhosis van, } \\
\mathrm{n}(\%)\end{array}$ & $\begin{array}{l}123 / 138 \\
(89 \%)\end{array}$ & $\begin{array}{l}65 / 123 \\
(53 \%)\end{array}$ & $\begin{array}{l}47 / 123 \\
(38 \%)\end{array}$ & $\begin{array}{l}48 / 123 \\
(39 \%)\end{array}$ & $\begin{array}{l}3 / 123 \\
(2 \%)\end{array}$ & $\begin{array}{l}10 / 123 \\
(8 \%)\end{array}$ \\
\hline Cirrhosis nincs, n (\%) & $\begin{array}{l}15 / 138 \\
(11 \%)\end{array}$ & $\begin{array}{l}4 / 15 \\
(26 \%)\end{array}$ & $\begin{array}{l}3 / 15 \\
(20 \%)\end{array}$ & $\begin{array}{l}6 / 15 \\
(40 \%)\end{array}$ & 0 & $\begin{array}{l}5 / 15 \\
(33 \%)\end{array}$ \\
\hline
\end{tabular}

Egyéb = 2 autoimmun hepatitis, 1 herediter haemochromatosis; MS = metabolikus szindróma; $\mathrm{n}$ = betegszám.

Azon betegeknek, akiknek nem volt májzsugora, leggyakrabban MS-ük volt.

(Kevert etiológiák miatt 1-1 beteg több etiológia alatt is szerepel. A nem cirrhosisos betegek etiológiai megoszlása: csak alkohol: 3 beteg, csak vírus: 1 beteg, vírus + MS: 1 beteg, vírus + alkohol + MS: 1 beteg, csak MS: 4 beteg, nincs adat: 5 beteg $=15$ beteg.) 
Korai stádiumban történt tumordiagnózis a cirrhosis felismerésétől függően

\begin{tabular}{ll}
\hline & $\begin{array}{l}\text { HCC diagnózisa a milánói } \\
\text { kritériumokon belül, } \\
\mathrm{n}(\%)\end{array}$ \\
\hline $\begin{array}{l}\text { Cirrhosis - HCC diagnózisa előtt } \\
(\mathrm{n}=71)\end{array}$ & $26 / 71(37 \%)$ \\
$\begin{array}{l}\text { Cirrhosis - HCC diagnózisakor } \\
(\mathrm{n}=52)\end{array}$ & $12 / 52(23 \%)$ \\
Cirrhosis nincs $(\mathrm{n}=15)$ & $4 / 15(26 \%)$ \\
\hline
\end{tabular}

n = betegszám

5. táblázat | Cirrhosis fennállásától függő túlélés

\begin{tabular}{lllll}
\hline & & $\begin{array}{l}\text { Összesen, } \\
\mathrm{n}(\%)\end{array}$ & $\begin{array}{l}\text { Túlélési idő } \\
(\text { nap })\end{array}$ & $\begin{array}{l}\text { Tumormentes } \\
\text { betegek, n }(\%)\end{array}$ \\
\hline $\begin{array}{l}\text { Cirrhosis, } \\
\mathrm{n}=138\end{array}$ & Van & $123 / 138(89 \%)$ & 372 & $7(6 \%)$ \\
\hline
\end{tabular}

$\mathrm{n}$ = betegszám

Cirrhosisról adat 138 beteg esetén állt rendelkezésre.

6. táblázat

Etiológiától függő túlélés

Egyéb = 2 autoimmun hepatitis, 1 herediter haemochromatosis

\begin{tabular}{|c|c|c|c|c|c|}
\hline & & $\begin{array}{l}\text { Össze- } \\
\text { sen, } \\
\mathrm{n}(\%)\end{array}$ & $\begin{array}{l}\text { BCLC-stádium, } \\
\mathrm{n}(\%)\end{array}$ & $\begin{array}{l}\text { Túlélési } \\
\text { idő } \\
\text { (nap) }\end{array}$ & $\begin{array}{l}\text { Tumor- } \\
\text { mentes } \\
\text { bete- } \\
\text { gek, } \\
\text { n }(\%)\end{array}$ \\
\hline \multirow{4}{*}{$\begin{array}{l}\text { Etiológia, } \\
\mathrm{n}=149\end{array}$} & $\begin{array}{l}\text { Alkohol } \\
\mathrm{n}=77\end{array}$ & $\begin{array}{l}77 / 149 \\
(52 \%)\end{array}$ & $\begin{array}{l}\text { A: } 13 / 77(17 \%) \\
\text { B-C: } 44 / 77(57 \%) \\
\text { D: } 20 / 77(26 \%)\end{array}$ & 423 & $\begin{array}{l}3 / 77 \\
(4 \%)\end{array}$ \\
\hline & $\begin{array}{l}\text { Vírus } \\
\mathrm{n}=61\end{array}$ & $\begin{array}{l}61 / 149 \\
(41 \%)\end{array}$ & $\begin{array}{l}\text { A: } 16 / 61(26 \%) \\
\text { B-C: } 33 / 61(54 \%) \\
\text { D: } 12 / 61(20 \%)\end{array}$ & 282 & $\begin{array}{l}2 / 61 \\
(3 \%)\end{array}$ \\
\hline & $\begin{array}{l}\text { MS } \\
n=65\end{array}$ & $\begin{array}{l}65 / 149 \\
(44 \%)\end{array}$ & $\begin{array}{l}\text { A: } 10 / 65(15 \%) \\
\text { B-C: } 42 / 65(65 \%) \\
\text { D: } 12 / 65(18 \%)\end{array}$ & 335 & $\begin{array}{l}6 / 65 \\
(9 \%)\end{array}$ \\
\hline & $\begin{array}{l}\text { Egyéb } \\
\mathrm{n}=3\end{array}$ & $\begin{array}{l}3 / 149 \\
(2 \%)\end{array}$ & $\begin{array}{l}\text { A: } 2 / 3(67 \%) \\
\text { B-C: } 1 / 3(33 \%)\end{array}$ & 1303 & 0 \\
\hline
\end{tabular}

$\mathrm{n}$ = betegszám

Etiológiára vonatkozóan 149 beteg esetén volt adatunk.

betegséget, szemben a korábban ismert cirrhosisos populációval, ahol a betegek $36 \%$-ában volt a tumor kurábilis stádiumban (4. táblázat). A vírusos eredet mellett kissé nagyobb arányú volt a korai stádiumban (BCLC A stádium) felismert daganat (26\%), az alkoholos és a metabolikus szindrómás csoport szignifikánsan nem különbözött (17\% vs. 15\%).

A medián túlélés alacsonyabb volt (372 nap), ha a daganat cirrhosis talaján alakult ki, szemben a nem cirrhosisos populáció 626 napos medián túlélésével. A tumor-
7. táblázat | HCC stádiumától függő túlélés

\begin{tabular}{|c|c|c|c|c|c|c|}
\hline & & $\begin{array}{l}\text { Összesen, } \\
\mathrm{n}(\%)\end{array}$ & $\begin{array}{l}\text { Nemzet- } \\
\text { közi adat }\end{array}$ & $\begin{array}{l}\text { Túl- } \\
\text { élési } \\
\text { idő } \\
\text { (nap) }\end{array}$ & $\begin{array}{l}\text { Nemzet- } \\
\text { közi adat } \\
(\text { nap) }\end{array}$ & $\begin{array}{l}\text { Tumor- } \\
\text { mentes } \\
\text { túlélés, } \\
\text { n (\%) }\end{array}$ \\
\hline \multirow{3}{*}{$\begin{array}{l}\text { Barcelona } \\
\text { stádium, } \\
\mathrm{n}=186\end{array}$} & A & $\begin{array}{l}32 / 186 \\
(17 \%)\end{array}$ & $30-60 \%$ & 829 & 1770 & $\begin{array}{l}5 / 32 \\
(16 \%)\end{array}$ \\
\hline & $\mathrm{B} / \mathrm{C}$ & $\begin{array}{l}118 / 186 \\
(64 \%)\end{array}$ & $20-30 \%$ & 387 & 795 & $\begin{array}{l}5 / 118 \\
(4 \%)\end{array}$ \\
\hline & $\mathrm{D}$ & $\begin{array}{l}36 / 186 \\
(19 \%)\end{array}$ & $20-30 \%$ & 137 & 435 & 0 \\
\hline
\end{tabular}

$\mathrm{n}=$ betegszám

Dőlt betûpvel a nemzetközi adatok [17], normálbetúvel a saját adatok szerepelnek.

8. táblázat | Cirrhosis súlyosságától függő túlélés

\begin{tabular}{lllllll}
\hline & $\begin{array}{l}\text { C-P } \\
\text { stá- } \\
\text { dium }\end{array}$ & $\begin{array}{l}\text { Összesen, } \\
\mathrm{n}(\%)\end{array}$ & $\begin{array}{l}\text { Nemzet- } \\
\text { közi } \\
\text { adat }\end{array}$ & $\begin{array}{l}\text { Túl- } \\
\text { élési } \\
\text { idő } \\
\text { (nap) }\end{array}$ & $\begin{array}{l}\text { Nemzetkö- } \\
\text { zi adat } \\
(\text { nap) }\end{array}$ & $\begin{array}{l}\text { Tumor- } \\
\text { mentes } \\
\text { betegek, } \\
\mathrm{n}(\%)\end{array}$ \\
\hline A & $\begin{array}{l}137 / 182 \\
(75 \%)\end{array}$ & $57,4 \% *$ & 489 & $730^{* *}$ & $10(7 \%)$ \\
$\begin{array}{l}\text { Cirrhosis- } \\
\text { stádium, } \\
\text { n=182 }\end{array}$ & B & $\begin{array}{l}36 / 182 \\
(20 \%)\end{array}$ & $34,4 \% *$ & 157 & $365^{* *}$ & 0 \\
& C & $\begin{array}{l}9 / 192 \\
(5 \%)\end{array}$ & $8,4 \% *$ & 133 & $90 * *$ & 0 \\
\hline
\end{tabular}

C-P stádium = Child-Pugh-stádium; $\mathrm{n}$ = betegszám

Dölt betüpel a nemzetközi adatok (*[18]; **[17]), normálbetűvel a saját adatok szerepelnek.

mentes betegek aránya is magasabb volt $(20 \%$ vs. $6 \%)$ a májzsugorban nem szenvedők között (5. táblázat).

A 6. táblázatban látható, hogy a három leggyakoribb etiológiai faktor közül a leghosszabb medián túlélés alkoholos eredet esetén adódott (423 nap), a legrosszabbat pedig vírusos eredet mellett észleltük (282 nap), de a köztük lévő különbség a jelentős szórás miatt nem volt szignifikáns.

A várhatónak megfelelően rosszabb volt a túlélés előrehaladottabb Barcelona tumorstádium (A: 829 nap, B/C: 387 nap, D: 137 nap), illetve súlyosabb ChildPugh-stádium (A: 489 nap; B: 157 nap; C: 133 nap) esetén is (7. és 8. táblázat) [17, 18]. A betegek jelentős része, sajnos, a daganat előrehaladott szakaszában kerül felismerésre, ráadásul az adott stádiumú betegek túlélése jelentôsen elmarad a nemzetközi értékektől, (7. táblázat) $[17,18]$.

A mütétet követő 3 és 5 éves túlélés (35\%, 15\%) sokkal rosszabb, mint az irodalomban olvasható adatok $(83 \%$, $76 \%$, amin csak kissé javít, ha kizárólag azon betegek túlélését vesszük figyelembe, akiknél a mütéti indikáció felállítása az ajánlásnak megfelelően történt (41\%,23\%). RFA-t 13 betegben alkalmaztak, közöttük ritkábban fordult elő, hogy a beavatkozás indikációja eltért az aján- 
9. táblázat | Választott kezeléstől függő túlélések

\begin{tabular}{|c|c|c|c|c|c|c|c|}
\hline & $\begin{array}{l}\text { Medián túlélés/ } \\
N A \\
\text { (nap) }\end{array}$ & $\begin{array}{l}3 ; 5 \text { éves túlélés/ } \\
\text { NA: 3; } 5 \text { éves túlélés (\%) }\end{array}$ & Indikáció & $\begin{array}{l}\text { Összesen, } \\
\mathrm{n}(\%)\end{array}$ & $\begin{array}{l}\text { Medián túlélési } \\
\text { idő (nap) }\end{array}$ & $\begin{array}{l}3 ; 5 \text { évet } \\
\text { túlélők aránya } \\
(\%)\end{array}$ & $\begin{array}{l}\text { Tumormentes } \\
\text { betegek, } \\
\mathrm{n}(\%)\end{array}$ \\
\hline \multirow{2}{*}{$\begin{array}{l}\text { Mütét, } \\
\mathrm{n}=46\end{array}$} & \multirow[t]{2}{*}{1113} & \multirow{2}{*}{$\begin{array}{l}35 \% ; 15 \% \\
83 \% ; 76 \% * * \\
{[20]}\end{array}$} & Helyes & $22 / 46(48 \%)$ & 1192 & $41 \% ; 23 \%$ & $5 / 22(23 \%)$ \\
\hline & & & Nem helyes & $24 / 46(52 \%)$ & 1055 & $29 \% ; 21 \%$ & $3 / 24(12,5 \%)$ \\
\hline \multirow{2}{*}{$\begin{array}{l}\text { RFA, } \\
\mathrm{n}=13\end{array}$} & \multirow[t]{2}{*}{889} & \multirow{2}{*}{$\begin{array}{l}46 \% ; 0 \% \\
63 \% ; 50 \% * *\end{array}$} & Helyes & $10 / 13(77 \%)$ & 904 & $50 \% ; 0 \%$ & $2 / 10(20 \%)$ \\
\hline & & & Nem helyes & $3 / 13(23 \%)$ & 841 & $33 \% ; 0 \%$ & 0 \\
\hline \multirow{2}{*}{$\begin{array}{l}\text { TACE } \\
\mathrm{n}=49\end{array}$} & \multirow[t]{2}{*}{$605 / 577^{*}$} & \multirow{2}{*}{$\begin{array}{l}14 \% ; 4 \% \\
29 \% ; 18 \% *\end{array}$} & Helyes & $43 / 49(88 \%)$ & 605 & $14 \% ; 2 \%$ & 0 \\
\hline & & & Nem helyes & $6 / 49(12 \%)$ & 609 & $16 \% ; 16 \%$ & 0 \\
\hline \multirow{2}{*}{$\begin{array}{l}\text { Sorafenib, } \\
\mathrm{n}=39\end{array}$} & \multirow[t]{2}{*}{$366 / 332$ ** } & & Helyes & $28 / 39(72 \%)$ & 283 & & 0 \\
\hline & & & Nem helyes & $11 / 39(28 \%)$ & 578 & & 0 \\
\hline \multirow{2}{*}{$\begin{array}{l}\text { Palliatív, } \\
\mathrm{n}=25\end{array}$} & \multirow[t]{2}{*}{$164 / 90^{* *}$} & & Helyes & $18 / 25(72 \%)$ & 161 & & 0 \\
\hline & & & Nem helyes & $7 / 25(28 \%)$ & 173 & & 0 \\
\hline
\end{tabular}

$\mathrm{n}$ = betegszám; $\mathrm{NA}=$ nemzetközi adat RFA = rádiófrekvenciás ablatio; TACE = transarterialis chemoembolisatio

Dőlt betűvel a nemzetközi adatok, normálbetűvel a saját adatok szerepelnek (*[19]; **[20]).

lottól (3 eset), ennek ellenére az irodalomban mutatott eredményeket nem sikerült reprodukálni ( 3 és 5 éves túlélés: $46 \%, 0 \%$ vs. $63 \%, 50 \%)$ [17]. A palliatív kezelések kapcsán a medián túlélés napokban számolva megközelíti a nemzetközi eredményeket [19], azonban a 3 és 5 éves túlélés százalékos arányát tekintve itt is lemaradásban vagyunk. Érdekes, hogy a helyesen és nem helyesen választott indikációk esetén hasonló túlélések adódtak, illetve sorafenibkezelés esetén hosszabb volt a túlélés az ajánlásba nem illeszthető indikáció esetén (9. táblázat) $[19,20]$.

A nem az ajánlás szerinti kezelések eseteit tovább vizsgáltuk (10. táblázat). Mütét kapcsán ezeknél a betegeknél a guideline-ok szerint csak palliatív kezelésre lett volna lehetőség (nem mutatott adat). A nem ajánlás szerint választott TACE-val kezelt 6 beteg közül a rendelkezésre

10. táblázat $\mid A z$ ajánlottól eltérő terápiás választások helyett a guideline szerint javasolt kezelések

\begin{tabular}{ll}
\hline Nem az ajánlásnak megfelelő & Ajánlás szerint \\
\hline TACE, & 4 beteg: RFA vagy mútét \\
$\mathrm{n}=6$ & 2 beteg: tüneti \\
\hline Sorafenib, & 4 beteg: RFA vagy mútét \\
$\mathrm{n}=11$ & 7 beteg: tüneti \\
\hline $\begin{array}{l}\text { Tüneti, } \\
\mathrm{n}=7\end{array}$ & 6 beteg: TACE \\
\hline
\end{tabular}

$\mathrm{n}=$ betegszám; TACE $=$ transarterialis chemoembolisatio.

A 6, TACE-vel kezelt beteg közül 4 alkalmas lett volna RFA-ra vagy reszekcióra, 2 csak tüneti terápiára. 11, sorafenibet kapott beteg közül 4 esetben a kuratív kezelést meg lehetett volna próbálni, 7 tüneti terápiára volt alkalmas. A 7, csak tüneti kezelésben részesített beteg aktívabb onkológiai kezelést kaphatott volna: 6 TACE-t, 1 sorafenibet. álló adatok alapján 4 RFA-ra vagy mútétre is alkalmas lett volna, kettőnél aktív onkológiai kezelés nem jött szóba. A rendelkezésre álló adatok alapján a sorafenibcsoportban 4 betegnek aktívabb kezelésre lett volna lehetősége. A 7, csak tüneti terápiát kapó beteg TACE( 6 beteg) vagy sorafenib- (1 beteg) kezelést kaphatott volna.

\section{Megbeszélés}

Eredményeink retrospektív adatgyưjtésből származnak, annak minden hibájával. Az adataink hiányosak, emiatt pontos statisztikai értékelésre nem alkalmasak, de az a tendenciákból is jól látható, hogy eredményeink elmaradnak a nemzetközi adatok alapján várhatótól. Nagyon fontos volna feltárni azokat az okokat, amelyek mindezt magyarázhatják.

Betegeink átlagéletkora, a nemek aránya nem tér el az egyéb helyeken észleltektől. Az etiológiai tényezők azonban jelentősen különböznek. A világstatisztikai értékek szerint a vírusos alapbetegség áll az első helyen 49\%-kal, a második az alkohol 26\%-kal, a NASH pedig 11\%-ban szerepel oki tényezóként [21].

Betegeink körében a HCC legfontosabb etiológiai tényezője az alkoholfogyasztás és a metabolikus szindróma következményeként kialakuló NASH, amelyek a helytelen életmóddal szorosan összefüggnek. Valószínúleg azonban számításaink alábecsülik az alkoholfogyasztás arányát, mivel az esetek 38\%-ában nem szerepel semmilyen információ az etilfogyasztással kapcsolatban (nem mutatott adat). Régiónkban a vírusok a harmadik helyen állnak, nem sokkal a NASH mögött.

A daganat megelőzése szempontjából az alkoholizmus visszaszorítása mellett fontos lenne a túlsúly elkerülése. 
A HBV-fertőzöttség hazánkban várhatóan csökkenni fog a fiatal korosztály védőoltásának bevezetésével, bár ezt a migráció módosíthatja. Jelentős a fejlődés a C-vírus-fertőzöttség terápiájában, így szintén várható etiológiai szerepének csökkenése.

Sajnos a betegség kialakulását megelőző cirrhosis csaknem az esetek felében a HCC diagnózisa idején került felismerésre. A betegek negyedében nem történt semmilyen vizsgálat a háttérben álló májzsugor diagnózisának irányába. Ennek pedig több szempontból is van jelentősége. Egyrészt befolyásolja a terápiás döntést, másrészt a nemzetközi és saját adataink is azt mutatják, hogy a máj átépülése jelentősen rontja a túlélést [22]. Fontos azért is, mert a cirrhosisos populációt szûrjük rendszeresen HCC irányában, így, ha ez nem tudott, várhatólag a daganat későbbi stádiumban kerül felismerésre. Ezt adataink is tükrözik. Azonban az ismert cirrhosisosok és nem ismert vagy nem cirrhosisos populáció között a korán felismert tumor arányát tekintve a különbség kicsi. A felmérések szerint az esetlegesen követett cirrhosisosokban 34,6\%-ban várható a tumor diagnózisa a milánói kritériumokon belül. A rendszeres szürések viszont 69\%-ban lehetővé teszik a korai stádiumban történő felismerést [17]. Ez azt jelenti, hogy a jelen tanulmányban szereplő májzsugorosok rendszeres szűrése nem történt meg.

A májcirrhosis nélkül kialakult HCC-seknek leggyakrabban metabolikus szindrómájuk volt, amely alapján feltételezhető, hogy a hátterében NASH állt. Ez az adat azonban a kis esetszám miatt nem biztos, hogy a valóságot hûen tükrözi, ráadásul az eredményt torzíthatja, hogy ebben a csoportban különösen magas arányban (az esetek egyharmadában) hiányzott az információ az etiológiával kapcsolatban.

A túlélést befolyásoló tényezők a tumorstádium, a cirrhosis jelenléte és súlyossága, illetve a választott terápia voltak. Betegeinkben a HCC felismerése gyakran későn, előrehaladott stádiumban történt, mindössze 17\%-ban volt a daganat korai, kurábilis szakaszban. Ez még a nem túl jónak mondható nemzetközi eredményekhez viszonyítva is nagyon rossz arány. A daganat korai felismerését a cirrhosisos beteganyag alaposabb, rendszeresebb ellenőrzése csak részben javítaná, mert jelentős hányaduk nem került volna bele az ellenőrzött csoportba (nem ismert vagy nem cirrhosisos). Megfontolandó lehet a vírusos és májzsugoros betegeken kívül a szürés kiterjesztése a nem alkoholos zsírmáj szempontjából veszélyeztetett obes, diabeteses betegekre. Kérdéses persze a hatékonyság, mivel a szúrésre használt ultrahang hatásfoka vastag hasfali zsírréteg esetén rosszabb.

A kezelések eredményessége az adott csoportokon belül is elmarad a publikációkban közölt adatoktól. Ha a mütéttel kezelt betegek esetén az elvárható 83\%-os 3 éves és 76\%-os 5 éves túléléseket [20] a jelen anyagból látszó 35, illetve 15\%-kal összevetjük, jelentős a különbség (9. táblázat) [19,20]. A betegek egy része még nem tart 5 évnél a követésben, így végső túlélésükkel nem tudtunk számolni. Ez azt jelenti, hogy a számok némileg javulhatnak. Ha azonban a tumormentesek arányát tekintjük, jelentős eredménymódosulásra a további követés során sem számíthatunk. A helyzet csak kicsivel jobb, ha csupán azon betegek adatait vesszük figyelembe, ahol a nemzetközi ajánlásnak megfelelően történt a sebészi reszekció indikációjának a felállítása. A reszekciót követő gyenge kimenetel valószínúleg nem mútéttechnikai vagy perioperatív gondozási hiba, mivel 30 napon belüli mortalitás csak egy esetben fordult elő. Sokkal valószínúbb az, hogy az alap májbetegség gondozása, kezelése maradt el. Kiragadott példa erre egy C-vírus-pozitív beteg esete, akinek kuratív mütétét követően nem történt antivirális kezelés, transzplantációs elbírálás, és 2 évvel később megjelent a második HCC-góc. Jelentôs törekvés, hogy a recidívairányú szürés mellett megtörténjen az etiológia tisztázása, lehetőség szerinti kiiktatása. Bár ez nem minden esetben előzi meg a kiújulást, mégis a beteg túlélésére jelentős hatással van. Megfelelő hepatológiai gondozást igényel maga a májzsugor is.

Érdekes megjegyezni, hogy a nem ajánlás szerinti mütéti indikáció esetén a túlélések (1055 nap) jobbak voltak, mint amit a következő lépcsőben adható TACE-kezeléssel el tudtunk érni (605 nap). A milánói kritériumon kívül eső tumorméret, de még megfelelő májfunkció mellett elvégzett mútét kisebb valószínúséggel kuratív, mégis - legalábbis eseteinkben - a túlélést javíthatja.

A kombinált kezelésekkel kapcsolatos vizsgálatok jelenleg folyamatban vannak. Egyes tanulmányok hasonló tendencia mellett szólnak. Kapitanov és munkatársainak metaanalízise a műtéti indikációval kapcsolatos korábbi guideline-ok változtatását sürgeti [23]. Az irodalom azonban egyelőre nem foglalt állást a mútéti tumorkisebbítés előnyei mellett.

RFA esetén ritkábban fordult elő az ajánlástól való eltérés. A megfelelően választott terápia esetén a 3 éves túlélés közelíti a nemzetközileg megadott számot, azonban a várható 5 éves túlélés 20\% lesz. (A két tumormentessé vált betegnek még nincs meg az 5 éves követési ideje, de várhatóan meglesz.) A nem ajánlás szerinti indikációval kezelt betegek 3 éves túlélése (841 nap) jobb, mint a helyette választható TACE eredménye lehetett volna régiónkban. Úgy tünik, hogy a mütéthez hasonlóan a tumorkisebbítésnek itt is lehet haszna, bár a kis esetszám miatt ezt egyelőre csak gondolatébresztésként értékelhetjük.

Valószínúleg csalóka adat a nem ajánlás szerinti indikációval TACE- vagy a sorafenibkezelést kapók hosszabb túlélése a guideline szerint megfelelően kezeltekhez képest. Ugyanis a rendelkezésre álló adatok alapján a betegek egy része aktívabb, esetleg hosszabb túlélést biztosító kezelésre is alkalmas lett volna (10. táblázat). Bár ezekben az esetekben nem lehetünk biztosak abban, hogy nem a rossz általános állapot, esetleg a beteg egyedi döntése alapján került az eset az adott kezelési csoportba. Ezek az információk a dokumentációkban nem szerepeltek. 


\section{Következtetések}

A HCC-s betegek kezelési eredménye nem megfelelő, rosszabb, mint a szerénynek mondható nemzetközi sikerek. A háttérben a késői felismerés a legfontosabb tényező, de valószínúleg az eredmények javíthatók lennének a megfelelő hepatológiai gondozás erósítésével is. Az irodalmi adatok is azt tükrözik, hogy a beteg túlélési esélyei ott a legjobbak, ahol az onkológus, a sebész, az invazív radiológus és a hepatológus a beteget közösen látják el, a terápiás döntést a lehetőségeket mérlegelve közösen hozzák meg [24]. Az alapbetegség tisztázása, a cirrhosis felismerése és ezek kezelése nem kevésbé fontos, mint az onkológiai ellátás.

Anyagi támogatás: A közlemény megírása, illetve a kapcsolódó kutatás anyagi támogatásban nem részesült.

Szerzői munkamegosztás: P. R: A Medsol-adatok kigyüjtése, rendszerezése, közremúködés a feldolgozásban, a szöveg megírása. V. Zs: A feldolgozás alapötlete, az adatgyưjtés szempontjainak meghatározása, az adatok rendszerezése és feldolgozása, a szöveg megírása. P. M., T. I.: Ellenőrzés, korrektúra.

Érdekeltségek: A szerzőknek nincsenek érdekeltségeik.

\section{Irodalom}

[1] Ferlay, J., Shin, H. R., Bray, F., et al.: Estimates of worldwide burden of cancer in 2008: GLOBOCAN 2008. Int. J. Cancer, 2010, 127(12), 2893-2917.

[2] But, D. Y., Lai, C. L., Yuen, M. F.: Natural history of hepatitisrelated hepatocellular carcinoma. World J. Gastroenterol., 2008, 14(11), 1652-1656.

[3] Pascual, S., Herrera, I., Irurzun, J.: New advances in hepatocellular carcinoma. World J. Hepatol., 2016, 8(9), 421-438.

[4] Tornai, I.: Role of environmental factors in the etiology of hepatocellular carcinoma. [A környezeti tényezők szerepe a hepatocellularis carcinoma kialakulásában.] Orv. Hetil., 2010, 151(28), 1132-1136. [Hungarian]

[5] Ronot, M., Vilgrain, V.: Hepatocellular carcinoma: diagnostic criteria by imaging techniques. Best Pract. Res. Clin. Gastroenterol., 2014, 28(5), 795-812.

[6] Trevisani, F., D'Intino, P. E., Morselli-Labate, A. M., et al.: Serum $\alpha$-fetoprotein for diagnosis of hepatocellular carcinoma in patients with chronic liver disease: influence of HBsAg and antiHCV status. J. Hepatol., 2001, 34(4), 570-575.

[7] Heuman, D. M., Gilles, H. S., Solomon, C., et al.: Should a radiological diagnosis of hepatocellular carcinoma be routinely confirmed by a biopsy? No. Eur. J. Intern. Med., 2012, 23(1), 3739 .

[8] Llovet, J. M., Di Bisceglie, A. M., Bruix, J., et al., for the Panel of Experts in HCC-Design Clinical Trials: Design and endpoints of clinical trials in hepatocellular carcinoma. J. Natl. Cancer Inst., 2008, 100(10), 698-711.

[9] Khan, A. S., Fowler, K. J., Chapman, W. C.: Current surgical treatment strategies for hepatocellular carcinoma in North America. World J. Gastroenterol., 2014, 20(41), 15007-15017.

[10] Livraghi, T., Giorgio, A., Marin, G.: Hepatocellular carcinoma and cirrhosis in 746 patients: long-term results of percutaneous ethanol injection. Radiology, 1995, 197(1), 101-108.

[11] Forner, A., Llovet, J. M., Bruix, J.: Hepatocellular carcinoma. Lancet, 2012, 379(9822), 1245-1255.

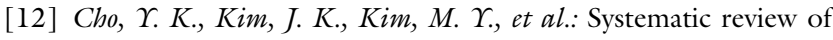
randomized trials for hepatocellular carcinoma treated with percutaneous ablation therapies. Hepatology, 2009, 49(2), 453459.

[13] Cucchetti, A., Piscaglia, F., Cescon, M., et al.: Systematic review of surgical resection vs radiofrequency ablation for hepatocellular carcinoma. World J. Gastroenterol., 2013, 19(26), 4106-4118.

[14] Cucchetti, A., Cescon, M., Trevisani, F., et al.: Current concepts in hepatic resection for hepatocellular carcinoma in cirrhotic patients. World J. Gastroenterol., 2012, 18(44), 6398-6408.

[15] Thomas, M. B., Jaffe, D., Choti, M. M., et al.: Hepatocellular carcinoma: consensus recommendations of the National Cancer Institute Clinical Trials Planning Meeting. J. Clin. Oncol., 2010, 28(25), 3994-4005.

[16] Waller, L. P., Deshpande, V., Pyrsopoulos, N.: Hepatocellular carcinoma: A comprehensive review. World J. Hepatol., 2015, 7(26), 2648-2663.

[17] Stravitz, R. T., Heuman, D. M., Chand, N., et al.: Surveillance for hepatocellular carcinoma in patients with cirrhosis improves outcome. Am. J. Med., 2008, 121(2), 119-126.

[18] Bolondi, L., Sofia, S., Siringo, S., et al.: Surveillance programme of cirrhotic patients for early diagnosis and treatment of hepatocellular carcinoma: a cost effectiveness analysis. Gut, 2001, 48(2), 251-259.

[19] Sangro, B.: Chemoembolization and radioembolization. Best Pract. Res. Clin. Gastroenterol., 2014, 28(5), 909-919.

[20] Llovet, J. M., Bruix, J.: Novel advancements in the management of hepatocellular carcinoma in 2008. J. Hepatol., 2008, 48(Suppl. 1), S20-S37.

[21] Yang, J. D., Kim, B., Sanderson, S. O., et al.: Hepatocellular carcinoma in Olmsted County, Minnesota, 1976-2008. Mayo Clin. Proc., 2012, 87(1), 9-16.

[22] Cho, Y. K., Kim, J. K., Kim, M. Ү., et al.: Systematic review of randomized trials for hepatocellular carcinoma treated with percutaneous ablation therapies. Hepatology, 2009, 49(2), 453459.

[23] Kapitanov, T., Neumann, U. P., Schmeding, M.: Hepatocellular carcinoma in liver cirrhosis: surgical resection versus transarterial chemoembolization - a meta-analysis. Gastroenterol. Res. Pract., 2015, 2015, Article ID 696120 .

[24] Barone, C., Koeberle, D., Metselaar, H., et al.: Multidisciplinary approach for HCC patients: hepatology for the oncologists. Ann. Oncol., 2013, 24(Suppl. 2), iil5-ii23.

(Vitális Zsuzsanna dr., Debrecen, Nagyerdei krt. 98., 4032 e-mail: vitalis@med.unideb.hu) 